\title{
Assessment framework of actor strategies in international river basin management, the case of Deltarhine
}

\author{
Tobias Renner $^{1}$ (iD $\cdot$ Sander Meijerink ${ }^{2}$ (D) $\cdot$ Pieter van der Zaag ${ }^{3,4}$ (i) $\cdot$ Toine Smits $^{5,6}$ (D)
}

Accepted: 30 September 2020 / Published online: 12 October 2020

(c) The Author(s) 2020

\begin{abstract}
The combined effects of socio-economic growth as well as climate change exert increasing pressure on international river basins and require dedicated cooperative efforts to jointly manage international rivers. Cooperative strategies drawn from scientific literature, empirical research and practitioner's handbooks are explored and clustered into six key dimensions of goals, instruments, structures, actors, leadership and resources to provide an assessment tool of actor strategies for both scientists and practitioners. The exploratory framework is applied to Dutch-German cooperation in the delta of the Rhine catchment, testing its conceptual validity and applicability in international river basin management as well as providing policy recommendations for the study area. The assessment framework can serve as an instrument to inventory, map and evaluate the importance of specific actor strategies and to facilitate dialogue and cross-border cooperation between riparian countries. Alternatively, the framework can be put to use, for example by downstream countries, to assess and coordinate their range of strategies on the national, regional and local level in order to engage and influence their counterparts.
\end{abstract}

Keywords Transboundary water regimes $\cdot$ Cross-border cooperation $\cdot$ Network management strategies - Assessment framework - International river basin management . Rhine

\section{Introduction}

International rivers constitute an important natural resource on our planet, and there has been an intensifying discussion in the past decades in the scientific and political arena how to further cooperation over these resources in the future. Background for this debate is the expectation that effects of population growth, socio-economic development and climate change (Hinkel and Menniken 2007; Delli Priscoli and Wolf 2009; Timmerman et al. 2011; Stefano et al. 2010; UNECE (United Nations Economic Commission for Europe) and

Electronic supplementary material The online version of this article (https://doi.org/10.1007/s 1078 4-020-09512-5) contains supplementary material, which is available to authorized users.

Tobias Renner trenner@brabant.nl

Extended author information available on the last page of the article 
INBO (International Network of River Basin Organisations) 2015) will exert increasing pressure on international river basins, introduce water stress and require dedicated cooperative efforts by riparian countries to equitably share water resources and economic benefits.

International organisations and financing institutions such as the Global Environmental Facility (GEF), Global Water Partnership (GWP) and the World Bank therefore continue to initiate initiatives for transboundary knowledge development and utilisation, capacity building of international river basin organisations and putting cross-border coordination mechanisms in place to influence and align billions of dollars of domestic water resources investments in shared river basins (GWP and INBO 2012). Programmes such as UNESCO's Potential Conflict to Cooperation Potential Program (UNESCO 2004), the global Transboundary Water Assessment Programme (UNEP (United Nations Environment Programme) 2016) or geographically focused efforts such as Cooperation in International Waters in Africa (CIWA) are only a few witnesses to the continuous large-scale efforts of riparian countries and international donors to spur joint action across borders in the 286 international river basins around the globe.

Certainly, there is an impressive historic track record of literally thousands of years of cross-border water cooperation and evidence has been presented to disprove the dire water war scenarios from 2000s by showing that international rivers can be powerful catalysts for cooperation (Wolf 1998; Sadoff and Grey 2002; Barnaby 2009). Nevertheless, Zeitoun and Mirumachi (2008) convincingly argue that in the complex setting of transboundary waters, various forms of conflict occur almost always alongside various forms of cooperation, ranging from 'stymied fuming to public displays of hostility'. (UNDP 2006; Zeitoun and Warner 2006; Daoudy and Kistin 2008). Scientific research as well as performance reviews and policy evaluations of investment programmes over the past decades have indeed repeatedly shown very mixed performance records of international transboundary water regimes in terms of effectiveness of cross-border river basin organisations (RBOs), compliance of riparian countries with water treaties and particularly the poor track record of (domestic) implementation of international agreements (Bernauer 2002; Gerlak 2007; Schmeier 2010).

Cross-border cooperation is thus widely advocated and stimulated but the question is raised, with increased urgency, how actors in riparian countries, can make transboundary water regimes more effective in terms of problem-solving and goal attainment (Young 2001; Bernauer 2002; Earle et al. 2013). Central theme of this study is therefore the assessment of strategies that actors do employ to shape, steer and manage cross-border cooperation in international rivers towards problem-solving in major issues areas (e.g. water pollution and allocation, flood protection, river restoration).

Main actors in international river basins are usually and foremost the national, regional and local government agencies of the riparian countries, while international donors and non-state and external actors such as NGOs, the epistemic community and local population may play an important role in specific river basins (Marty 2001; Mostert 2003; Kistin 2007; Schmeier 2010; Herten 2011). International river basin management being firmly rooted in the public domain due to its public good and international relations character, the term 'actor' in this study denotes government actors unless otherwise indicated.

In the search for a conceptual tool to assess actor strategies, we build on both, social science research and the practitioner's literature on the topic. The rich body of social science literature since Le Marquand's landmark study in the 1970s is aware of the complex characteristics under which cooperation in international rivers occurs, such as sovereignty of nation states coupled to the absence of central authority and securitisation of water resources, the asymmetric upstream-downstream power constellations in many river basins or the two-level game of international treaties and 
domestic implementation; and social scientists have put forward a broad range of conceptual models based on empirical evidence and social science theories, (Marquand 1977; Young 1982; Levy et al. 1995; Bernauer 2002; Verwijmeren and Wiering 2007; Schmeier 2010; Earle et al. 2013; Schmeier et al. 2015). The scientific literature includes often river basin and case-specific policy recommendations, lessons learnt and management strategies (Bernauer 2020); however, the current literature on actor strategies is rather modest in scope. While specific strategies, for example for negotiations (Dinar 2008), are described, few publications are dedicated to a detailed discussion of overall process and management strategies that actors employ (Marty 2001; Mostert 2005; Van der Molen 2011; Wiering and Verwijmeren 2013). These strategies, however, are of central interest in this study as we seek to assess how actors, represented by key individuals such as negotiators, political leaders, mediators and facilitators, can use variegating sets of strategies to cope with challenges and barriers of cross-border cooperation, such as different goals and interests, structural differences between the riparian's legal and institutional framework or different cultural settings.

Next to social science research, there is a second body of practitioner's literature on international river basin management, comprising handbooks, policy briefs and advisory studies, lending guidelines and performance reviews with a focus on providing prescriptive policy advice to organise and steer cross-border cooperation. Here, international river basin management is mostly viewed through the practitioner's lens focusing on how to manage transboundary waters (SIDA 2001; UNESCO 2004; GWP 2012; UNECE and INBO 2015; UNEP 2016). There are notable examples where practitioner's advice and best practices of transboundary water management are combined with, and informed by, social science frameworks (Van der Zaag and Vaz 2003; Mostert 2005; Gerlak 2007; Bernauer and Kalbhenn 2009; Huntjens 2011; Van der Molen 2011; Grey et al. 2016), in general however, policy recommendations and lessons learnt from scientific literature seem to go largely unheeded. Mollinga (2010) has summarised the difficulties to provide scientific knowledge to decision-makers and practitioners, describing different routes that social science has taken, notably the analytical route of comprehensive, explanatory modelling and the assessment route of pragmatic frameworks for mapping and evaluation. This latter approach is pursued in this study to develop an exploratory assessment framework to map and evaluate actor strategies, as summarised in the central research question:

What sets of strategies do actors employ and consider important to shape, steer and manage cross-border cooperation in international rivers?

The remainder of the paper is structured as follows: the next section starts by introducing and operationalizing the assessment framework. The third section describes methodology and data collection. The fourth section describes the findings on relevant sets of actor strategies, building on social science and practitioner's literature. In the fifth section, the assessment framework is applied to a Dutch-German study area in the delta of the Rhine catchment to test its applicability as well as to gain insight which strategies Dutch and German actors from government agencies are using in their daily IRBM practice. The last, sixth section discusses the findings and conclusions, appraises the exploratory assessment framework and provides policy recommendations for the study area. 


\section{Conceptual framework}

\subsection{Actor strategies and the cyclic process of cross-border cooperation}

Cross-border cooperation and conflict in international rivers have been analysed using a broad range of social science theories, frameworks and approaches (Marty 2001; Mostert 2003, 2005; Dombrowsky 2007; Verwijmeren and Wiering 2007; Raadgever et al. 2008; Schmeier 2010; Bernauer and Kalbhenn 2009; Wiering et al. 2010). Regardless of their theoretical underpinning, most authors are guided explicitly or implicitly by the schematic framework as shown in Fig. 1, visualizing the cyclic process of regime formation and policy implementation in international river basins.

The potential for conflict and cooperation (Zeitoun and Mirumachi 2008) is foremost determined by the environmental, institutional, socio-economic, political and cultural context in the riparian countries. Cooperative regimes can then develop with agreed rules and procedures taking on various guises: from institutionalised international river basin commissions to low-key cross-border working groups, from formal binding treaties to informal shared practices, and from joint action programmes to separate domestic implementation plans. With the necessary resources and instruments at hand the agreed goals and measures can then be jointly or domestically implemented, to solve the problems for which they were created, changing the contextual landscape and the potential for conflict or cooperation, and thus starting a new round and policy cycle. External contextual changes and eventsoutside the direct influence of actors - can hinder, block and destroy cooperative efforts, but they also can be purposefully exploited as policy windows. In assessing actor strategies, it is of interest to appraise the catalytic role that 'focusing events' (Brouwer and Huitema 2015) and windows of opportunity (Kingdon 1997) can play in launching ideas, articulating policy proposals, generating political momentum and mobilising resources for cross-border cooperation (Renner and Meijerink 2018).

Though a useful analytical construct, the concept of a cyclic process and successive stages represents of course a rather idealised notion of cross-border cooperation. In the real world, transboundary water management often takes an altogether different course: riparian countries may not come to the table at all to talk and negotiate. Moreover, once cooperative water regimes are formed, it is certainly not granted that cooperation is effective in terms of environmental problem-solving as international RBOs may become 'paper tigers' due to missing mandates or implementation of measures is stymied due to lack of resources (Zeitoun and Mirumachi 2008; Öjendal et al. 2013; Grey et al. 2016). Moving from one

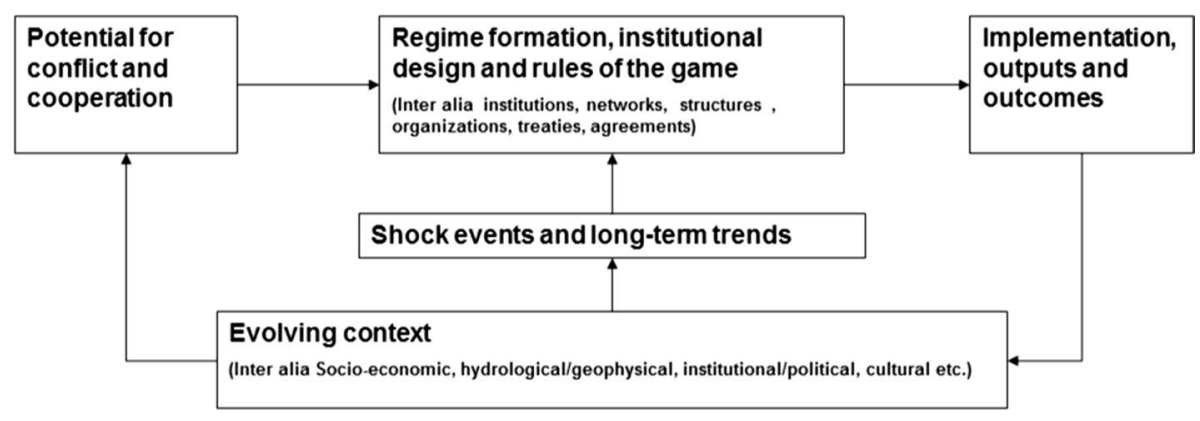

Fig. 1 Transboundary water regimes as a cyclic process, based on Mostert (2005) 
'stage' to another (as denoted in Fig. 1 by arrows) thus requires conscious efforts, leadership and substantial resources by the riparian actors, and the assessment of strategies these actors employ is the central topic of this study.

The twofold assessment of these actor strategies focuses first on regime evolution and design and related strategies to progress from information sharing, agenda setting, policy formulation to the creation of transboundary institutions and international treaties to finally arrive at implementation of measures for joint river basin management and problem-solving (further discussed in Sect. 4.1). Second, time can be a valuable resource in shaping international cooperation (Marty 2001; Mostert 2003, 2008; Grey et al. 2016) and analysing cross-border cooperation over a longer period of time allows to assess actor strategies in response to contextual changes, either gradual and incremental or abrupt due to what has been termed shock or emblematic events (Turton 2003; Lindemann 2008; Bressers and Kuks 2013), such as natural disasters, landmark meetings or election outcomes (further discussed in Sect. 4.2).

\subsection{Towards an assessment framework of actor strategies}

Comprehensive literature reviews have been carried out in the past to analyse the process of evolution, design and effectiveness of transboundary water regimes and study the influence of contextual changes. In this study, the multitude of explanatory factors and corresponding actor strategies from scientific literature as well as practitioner's handbooks is mapped, clustered and arranged following the practice-oriented route of assessment frameworks (Mollinga 2010).

In the search for a suitable, relatively parsimonious assessment framework, various conceptual models were considered, such as Ostrom's IAD framework (Pahl-Wostl et al. 2010; Santbergen 2013), network management theories (Meijerink 1998; Van der Molen 2011), policy arrangements approach (Arts and Van Tatenhove 2000; Wiering et al. 2010) and the environmental regime theory (Lindemann 2008; Raadgever et al 2008; Bressers and Kuks 2013). In particular, Wiering et al. (2010) and Bressers and Kuks (2013) employ a limited number of key dimensions to describe and assess major characteristics as well as dynamics of water governance regimes and to analyse and combine explanatory variables. Based on their work, we use a simplified set of 5 key dimensions to cluster and categorise the most important and relevant actor strategies variables into an assessment framework: objectives, instruments and resources as basic ingredients of any policy domain, the actors involved as well as the structures ordering their coalitions and interactions. In this study, a sixth key dimension of leader- and entrepreneurship is introduced and added, emphasizing the role and importance of key individuals in environmental governance regimes and cross-border cooperation in international rivers (Le Marquand 1977; Durth 1996; Levy et al. 1995; Van der Molen 2011; Subramanian et al. 2012; Grey et al. 2016; Renner et al. 2017; 2018). In Table 1, an overview of the six key dimensions is provided, followed by a brief description of each component.

Each of these key dimensions is considered necessary, yet not sufficient in itself to analyse and assess cross-border governance regimes. The six key dimensions are closely linked to each other and mutually interdependent.

Objectives: Each riparian country is bringing its own objectives, interests and ambitions to the table. This is where much analysis and advice is provided in the literature and practitioner's handbooks on negotiation strategies to deal with asymmetric interest and power constellations to overcome negative externalities; the creation of win-win 
Table 1 Key dimensions of the assessment framework and brief description

\begin{tabular}{ll}
\hline Key dimension & Brief description \\
\hline $\begin{array}{l}\text { Objectives } \\
\text { Policy instruments }\end{array}$ & $\begin{array}{c}\text { Aligning the different goals, ambitions and interests of riparian countries } \\
\text { Using available cross-border and domestic policy instruments and technological solu- } \\
\text { tions to achieve objectives } \\
\text { Linking the institutional and organisational structures of riparian countries, including } \\
\text { networks of non-governmental actors }\end{array}$ \\
$\begin{array}{l}\text { Connecting and committing actors and people in the different riparian countries } \\
\text { Resources }\end{array}$ & $\begin{array}{c}\text { Securing adequate resources and tools (financial, human, knowledge, legal, property } \\
\text { rights) }\end{array}$ \\
$\begin{array}{l}\text { Leadership and } \\
\text { entrepreneurship }\end{array}$ & purposefully steer and manage cross-border cooperation \\
\hline
\end{tabular}

situations to jointly reap benefits from sharing water resources, as well as issue linkage to other policy domains to arrive at joint agreements and finally implementation. Policy outcomes, goal attainment and problem-solving are at the heart of this key dimension. This is closely linked to the key dimension of Policy instruments and solutions, focusing on how agreements and joint policies can be crafted and implemented on the ground. This key dimension touches on the available cross-border policy tools and incentives, extensively discussed by Marty (2001), but also on the available domestic policy instruments and legal framework, domestic investment programmes and technological solutions in each riparian country.

Structures or getting the institutional design right of transboundary regimes, also termed multi-level transboundary water governance regimes, is a third key dimension where 3 aspects are often mentioned in the literature: the institutional and organisational design of transboundary institutions, how to effectively involve the respective governmental actors from the local up to the (supra)national level, thus parting ways with state-centric approaches, and the extent to which external stakeholder involvement is organised and managed from other policy domains, the epistemic community, private parties and citizens. The fourth key dimension of Actors might also been called 'people' as this term describes the range of network management strategies that are employed to connect people across borders, to build mutual trust, to forge personal relationships and to understand the cultural values, practices and hierarchies in which the people are operating, including language barriers.

Resources as the fifth key dimension are likewise crucial to all stages of cross-border cooperation, with financial and human transaction costs, possible compensation payments, investment costs in measures and water infrastructure but also legal and spatial resources (property rights) for implementation and information resources for joint knowledge bases. This key dimension features prominently in practitioners' handbooks, donor guidelines and policy briefs.

Finally, Leadership and entrepreneurship are seen as the sixth important key dimension to move, manage and steer transboundary regimes. Current literature and policy advice, with few exceptions, are largely silent on the role and importance of key individuals such as politicians, negotiators, delegation leaders or facilitators who are, however, the addressees of policy-oriented advice and conclusions provided by many scientific publications and practitioner's handbooks. This key dimension emphasises the importance of 
key individuals who are indispensable to purposefully employing strategies and steering cross-border cooperation, and is in line with the broader literature on transboundary, environmental regimes (Young 1991; Levy et al. 1995) and publications on international river basin management (Van der Molen 2011; Subramanian et al. 2012; Grey et al. 2016; Renner and Meijerink 2018; Renner et al. 2018).

Summarising, in this section we explored available frameworks from social science literature to describe and analyse complex governance regimes. We looked at the applicability of these frameworks to the field of transboundary water regimes in order to adopt and develop an assessment framework with a limited number of key dimensions. The assessment framework with its six key dimensions-objectives, instruments, structures, actors, resources and leadership_-is used to categorise and cluster sets of explanatory factors and corresponding actor strategies from the scientific and practitioner's literature (Sect. 4) with subsequent application of the framework to the Dutch-German study area in the delta of the river Rhine (Sect. 5).

\section{Methodology and data collection}

In this study, a framework for assessing actor strategies in international river basin management is developed and applied, and in order to do so, a two-step methodology was followed. First, we consulted scientific literature on transboundary water regimes, specifically focusing and building on comprehensive literature reviews and forward literature search to identify sets of explanatory factors, policy recommendations and corresponding strategies to be analysed and ordered (Marty 2001; Bernauer 2002; Mostert 2003; Verwijmeren and Wiering 2007; Raadgever et al. 2008; Schmeier 2010; Earle et al. 2013). In addition, use was made of, what is termed practitioner's literature, comprising handbooks, publications and papers looking at the practice of transboundary water management to identify additional criteria and actor strategies from international knowledge repositories and donor agencies (SIDA 2001; UNESCO 2004; GWP (Global Water Partnership) and INBO (International Network of Basin Organizations) 2012; UNECE (United Nations Economic Commission for Europe) and INBO (International Network of River Basin Organisations) 2015, UNEP (United Nations Environment Programme) 2016; TFDD (Transboundary Freshwater Dispute Database) (2017)). In collective brainstorming sessions, the different sets of actor strategies were evaluated by the authors and clustered into the identified key dimensions. In Sect. 4, these findings are described and reported.

Second, the assessment framework was applied to study a regional Dutch-German water regime in the delta of the Rhine catchment. Deltarhine, in short, is one of the 9 river basin sub-districts in which the Rhine basin was divided under the European Water Framework Directive (German Federal Ministry of Water Affairs 2009). The study area comprises about a third of the Dutch-German border and contains the shared regional river systems of Vecht-Dinkel, Berkel and Oude IJssel River at the focus of this study (Fig. 2).

The study area is characterised by nearly 6 decades of uninterrupted cooperation, a variety of cross-border issues ranging from flood protection, water pollution, and river restoration to spatial development schemes (Keetman 2006; Van Leussen et al. 2007; Van Herten 2011; Van der Molen 2011; Wiering and Verwijmeren 2013; Renner et al. 2017, 2018). The study area was selected for its empirical richness with different venues of cross-border cooperation, and the fact that is well-documented with policy documents, reports, archival records and publications (an overview is presented in the Electronic Supplementary 


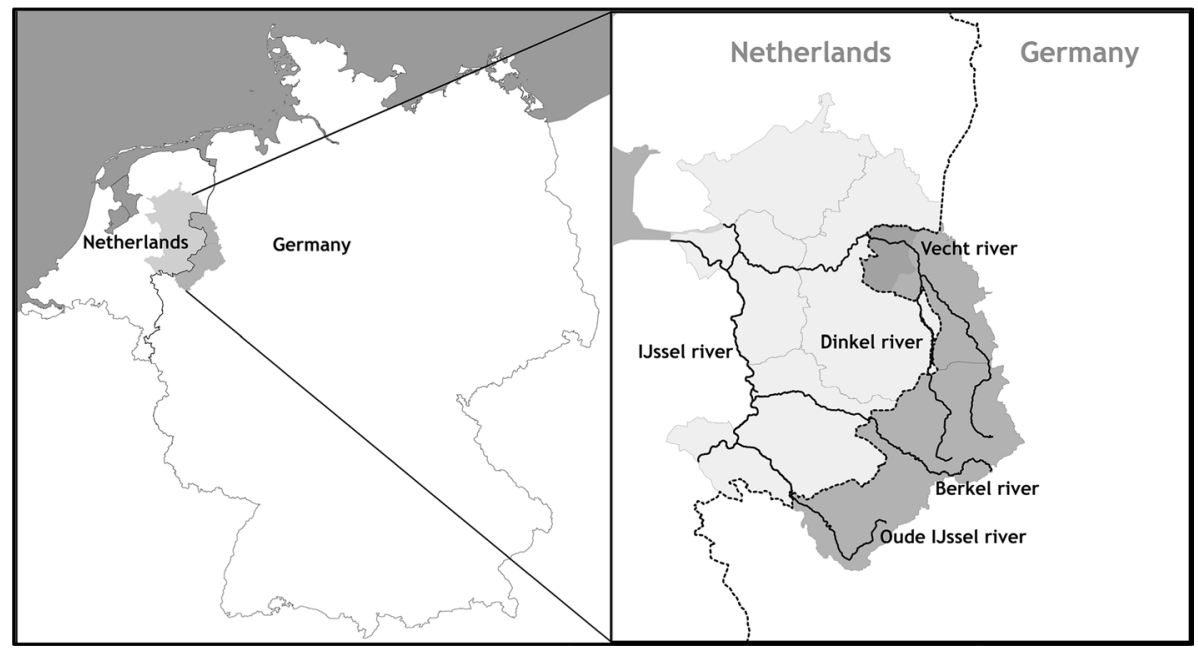

Fig. 2 Overview map of the study area in Deltarhine

Material (ESM), Table S1) Furthermore, it provides a relatively simple and bilateral setting with 2 riparian countries to apply and test the framework in an exploratory manner, of course with obvious limits to the general inferences that can be drawn from the case study.

The assessment framework and its application were discussed with key individuals and practitioners from subnational government agencies in both countries in the study area, upstream Germany and downstream Netherlands (Renner and Meijerink 2018). The assessment framework was applied in 2 ways: First, a scoring procedure was used to document how different actors see the importance of specific strategies in the venues of cross-border cooperation in which they were jointly involved (Renner et al. 2017). Respondents from upstream and downstream countries, in this case Germany and the Netherlands, may assign quite different scores to strategies such as using uncontested information, crafting joint policies, signing formal treaties or securing adequate financial and human resources. This instructive information was made explicit by asking respondents to assign qualitative weights to particular strategies and denoting their relative importance in Deltarhine with 'rather unimportant' (1), 'important' (2) and 'crucial' (3). Second, a scoring procedure was used to assess to what extent specific actor strategies are indeed employed in Deltarhine. Respondents were asked whether specific strategies were actively used in Deltarhine by assigning qualitative scores with a three-step grading: 'rather not' (1), 'regularly' (2), and 'often' (3), in order to document perceptions and observations on the current state of crossborder cooperation. The individual scores were averaged, first for the respondents from each country and then combined for overall synthesis. The scoring was complemented with narrative comments by the respondents with regard to particular strategies, which were recorded and documented. Interviews were conducted in German and Dutch to make it easier for the respondents to provide argumentation in their own language and express themselves precisely. The findings for the study area are reported in Sect. 5.

The empirical material, including the individual, anonymised scoring tables as well as for each country, is provided in the Electronic Supplementary Material (ESM), table S1-S4. The possible limitations and improvements of the methodology are discussed in Sect. 6. 


\section{Findings}

\subsection{Actor strategies in international river basin management}

In the past decades, an extensive body of scientific and practitioner's literature has been analysing cross-border cooperation in international rivers and factors of success (or failure) and policy recommendations have been provided concerning the formation, evolution and effectiveness of transboundary water regimes (SIDA 2001; UNESCO 2004; UNDP 2006; Verwijmeren and Wiering 2007; Schmeier 2010; GWP (Global Water Partnership) and INBO (International Network of Basin Organizations) 2012; Earle et al. 2013; Bernauer and Böhme 2014; UNECE (United Nations Economic Commission for Europe) and INBO (International Network of River Basin Organisations) 2015; Grey et al. 2016; UNEP 2016).

In Table 2, relevant actor strategies are listed, ordered and categorised for each of the six key dimensions, and linked to policy recommendations, lessons learnt and factors of 'success or failure' from multiple sources in the scientific and practitioner's literature. Due to length restrictions, the extended table, including more detailed description of the strategies, literature references and keywords is provided in the ESM, Table S2. Three main observations are provided regarding compilation and clustering of actor strategies:

First, the appraisal of literature reviews and practitioner's handbooks shows a broad range of several dozens of explanatory factors and corresponding actor strategies, to name but a few: demand for problem-specific cooperation, consensus on fundamental principles and norms, comparable institutional structures, clear mandates of international river basin organisations, enforcement mechanisms in water treaties, quality of delegations, creation of win-win situations and feasible solutions, leadership commitment, availability of data and information, third-party assistance, domestic legislation, issue-specific confidence building, commitment of politicians, importance of key individuals, financial side payments, shock events opening windows of opportunity etc. (Le Marquand 1977; Marty 1997; Verwijmeren and Wiering 2007; Schmeier 2010; Earle et al. 2013). This list is not exhaustive but nevertheless illustrates the methodological problem of establishing cause-effect relationships between a handful of indicators describing the effectiveness and performance of cross-border cooperation (the dependent variables) and a multitude of explanatory factors (i.e. independent variables).

Second, scientific publications often include lessons learnt or policy recommendations, which are mostly river basin specific and context-bound, or as some authors poignantly remarked, "proposing (presumably) effective or efficient management strategies and arguing rather eclectically with empirical illustrations, or making claims on the basis of pure theory..." (Bernauer 2002, p. 2). Giving voice to a practitioner's perspective, Grey et al. (2016) have looked at the track record of cooperation in international rivers in the past decades, and state that management strategies are a crucial element in building cooperative transboundary institutions, e.g. knowledge, trust and confidence among co-riparian states by establishing effective communications, working relationships and a level playing field of knowledge and skill is essential. These 2 citations, mirrored in the broader literature, illustrate and support the argument for a structured analysis of process and network management strategies (Mintrom and Norman 2009; Huitema and Meijerink 2009).

Third, the actor strategies in Table 2 provide a general overview of the available arsenal of strategies. It is noted, that the literature is broadly in agreement on explanatory factors and corresponding strategies with few exceptions (Dieperink 2002; Tschanz 2001; Marty 2001), although the relative importance of specific factors and strategies is strongly dependent on the 


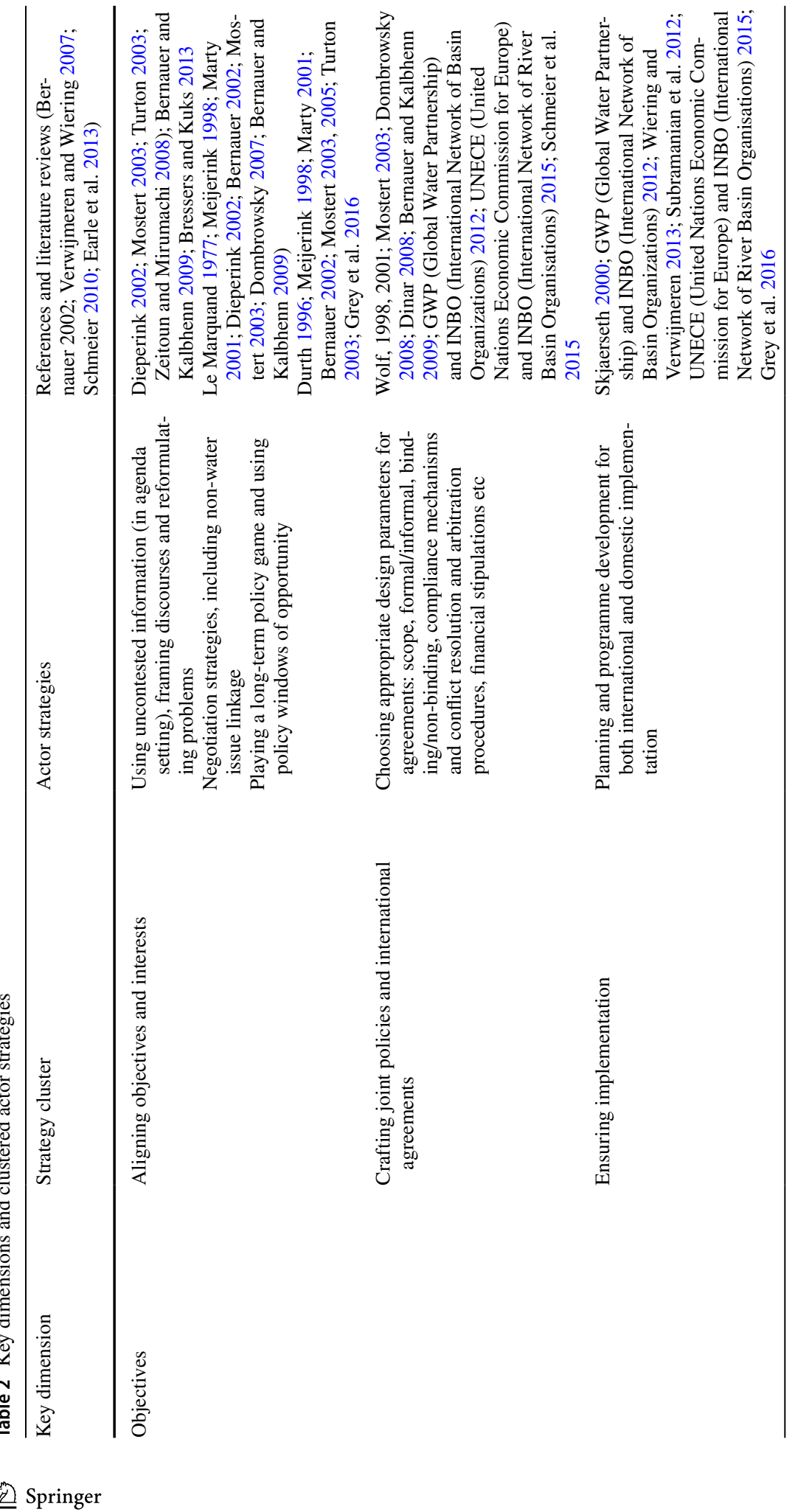




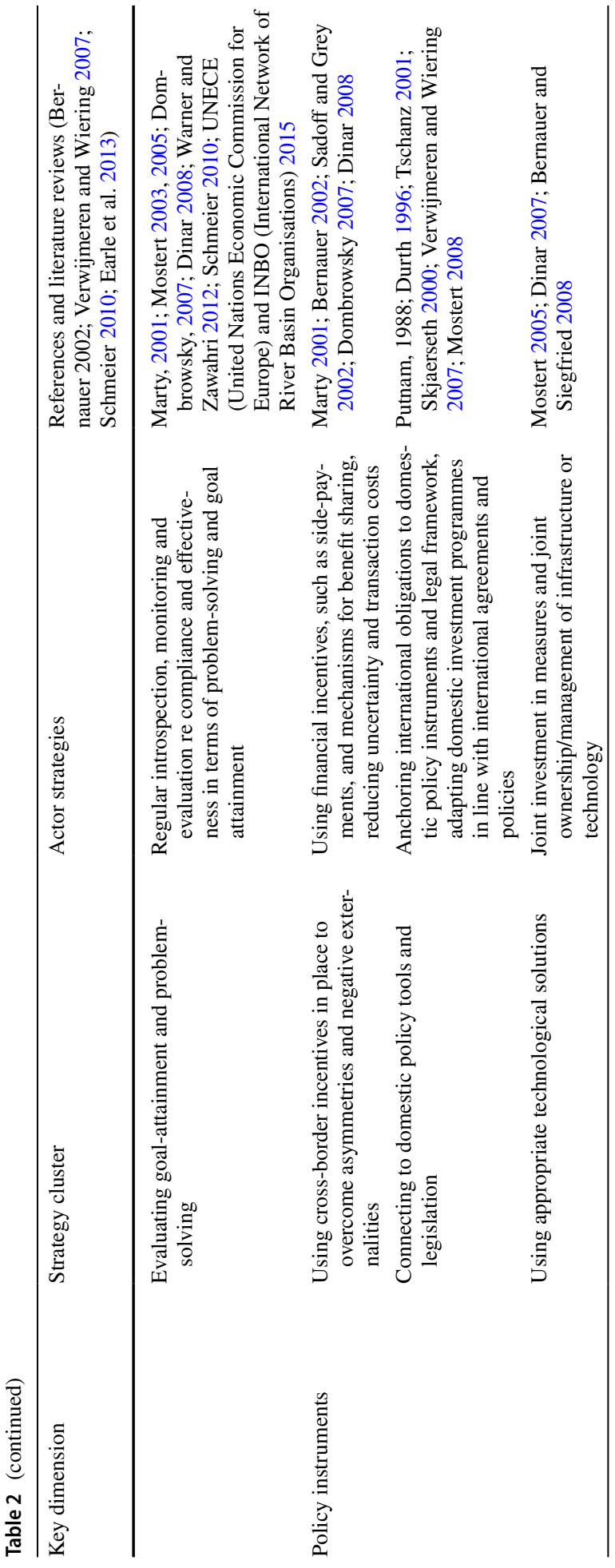




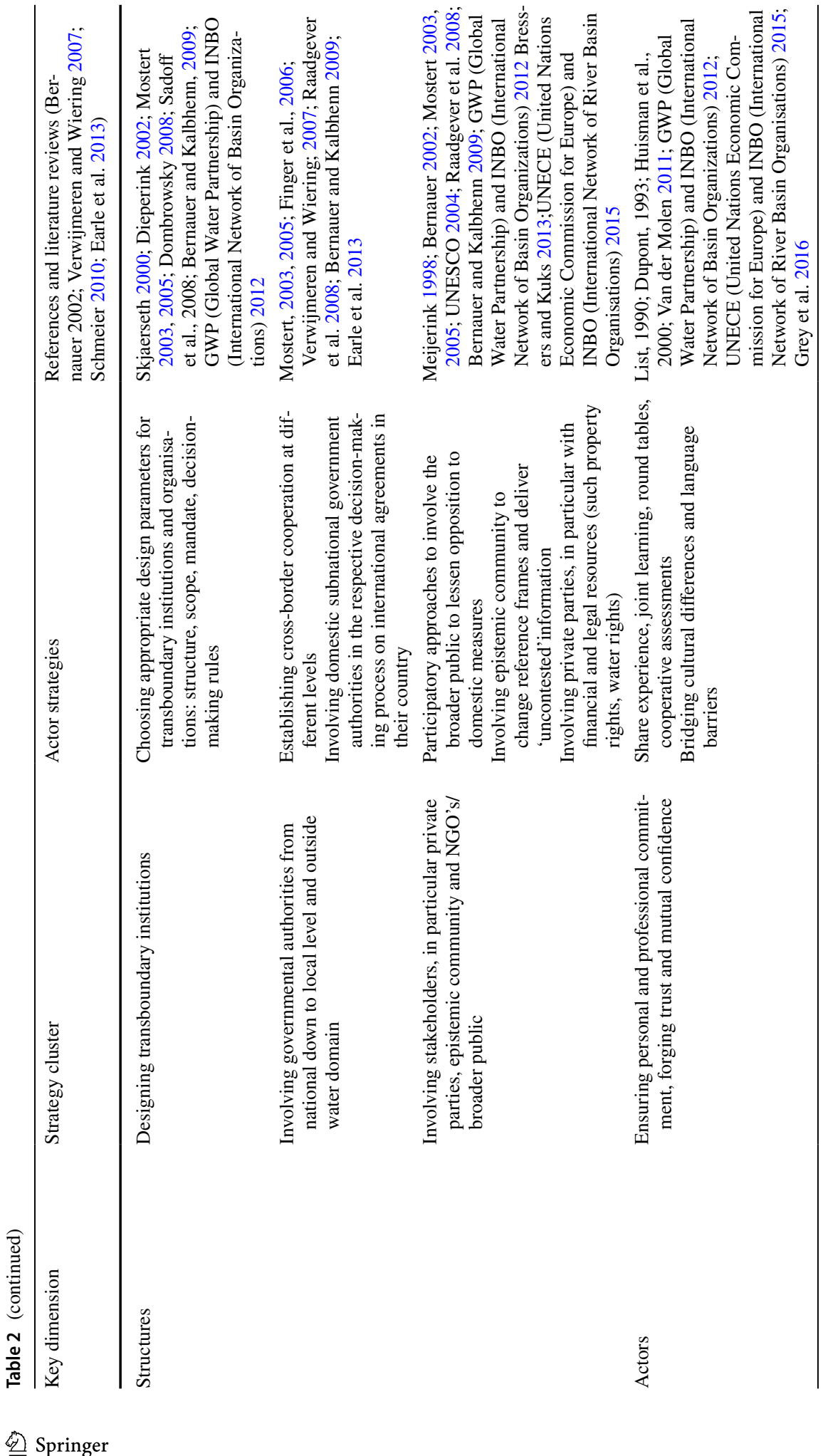




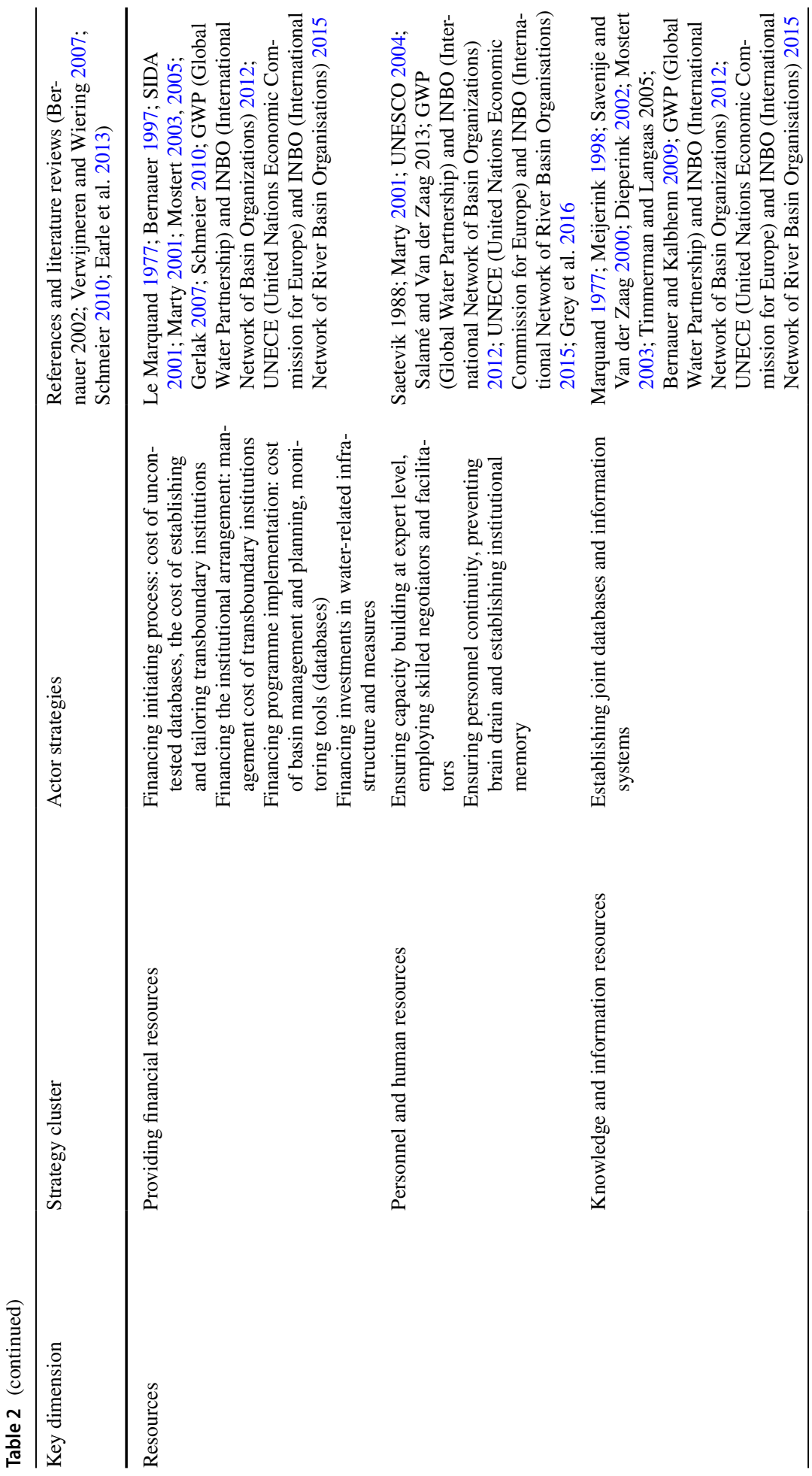




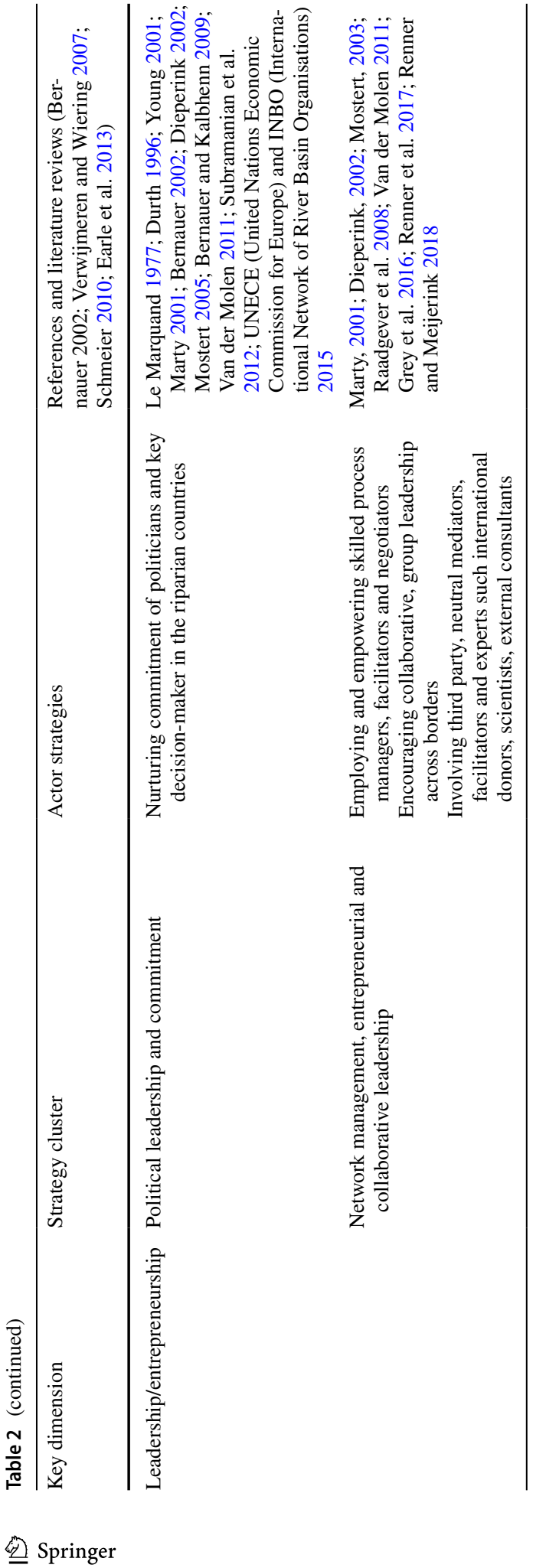


context and setting of each international river basin. It is therefore to be expected that not all strategies will be equally relevant for each river basin, this is further explored in the testing and application of the assessment framework in the study area of Deltarhine in Sect. 5.

\subsection{Dealing with gradual long-term developments as well as shock events}

Transboundary water regimes change and evolve (Young 1982), especially at the time scale of decades and generations. As Bressers and Kuks (2013) remarked: regimes can be stable, without much change or only gradual, incremental changes over long time periods, which are interspersed by short periods of radical change, caused by external factors like a natural disaster or man-made factors such as political crises; and several theories have been developed to describe these processes in detail (Sabatier and Jenkins-Smith 1993; Jones and Baumgartner 2012). Gradual physical, socio-economic, institutional, political and cultural developments lead to incremental adaptation of regimes over time, combined with important shock or emblematic events opening windows of opportunity for more radical change (Kingdon 1997). We referred to this ongoing influence as shock events and long-term trends in Fig. 1.

Cross-border cooperation in international rivers often spans decades, if not centuries (Marty 2001) and indeed, transboundary water regimes are not static and have been characterised as resilient over long periods of time (Wolf et al. 2003a, b; Delli Priscoli and Wolf 2009). Detailed accounts of the evolution of transboundary water regimes over many decades have been provided for example by Meijerink (1998), Van der Zaag and Vaz (2003), Dieperink (1997), Renner et al. (2018). Time is the arbiter of effectiveness and performance of transboundary water regimes, and while many current international river basin organisations may be described as ineffective and cooperative regimes as weak, various authors have convincingly argued that patience is advisable since international river basin management is a longterm endeavour easily spanning several decades and judgement should not be passed too early.

The capability of actors to adapt to changing circumstances or even exploit (policy) windows of opportunity as well as the adaptive capacity of transboundary institutions and the needed flexibility of international agreements have therefore also been described as an important explanatory factor for the performance of cooperative agreements (Le Marquand 1977; Young 1999; Marty 2001; Drieschova et al. 2008). For each of the key dimensions in the assessment framework, there are important long-term changes and short-term events that can change the course of cross-border cooperation. Table 3 lists, non-exhaustively and based on the consulted literature, a number of gradual long-term developments as well as shock events that can be included in the assessment of actor strategies to deal with contextual changes, to strengthen resilience of transboundary institutions and to exploit windows of opportunity over longer time periods.

\section{Application of the assessment framework to the Deltarhine case}

\subsection{Assessment of actor strategies in the Deltarhine regime}

In this section, we apply the assessment framework to German-Dutch cooperation in the regional shared rivers of Deltarhine, one of the 9 WFD river basin subdistricts of the Rhine basin. Deltarhine is the most downstream subcatchment of the Rhine and is shared by Germany and the Netherlands, with the latter being the downstream party. Cross-border cooperation in the shared regional rivers in Deltarhine, though sanctioned at the national level, 


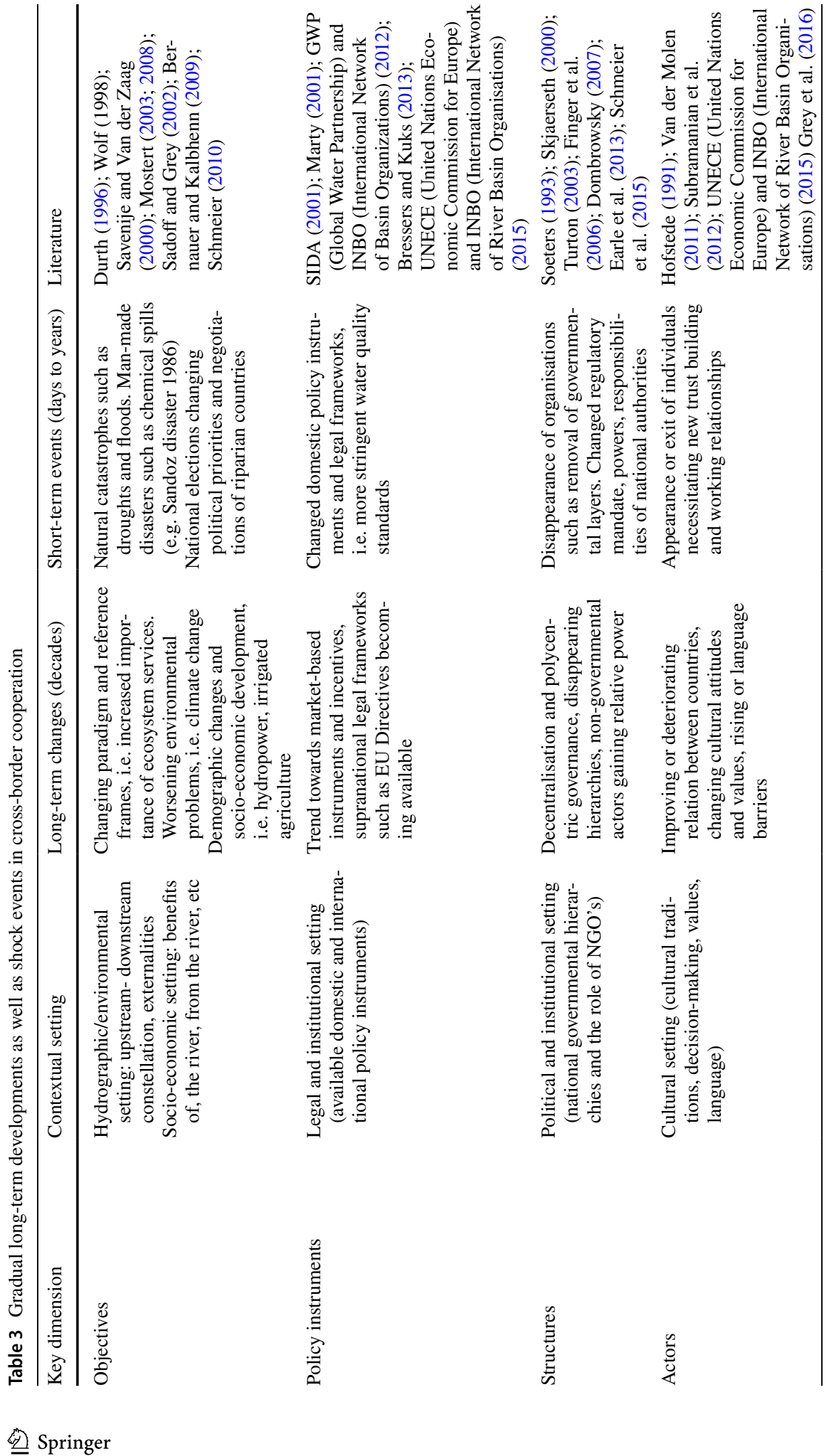




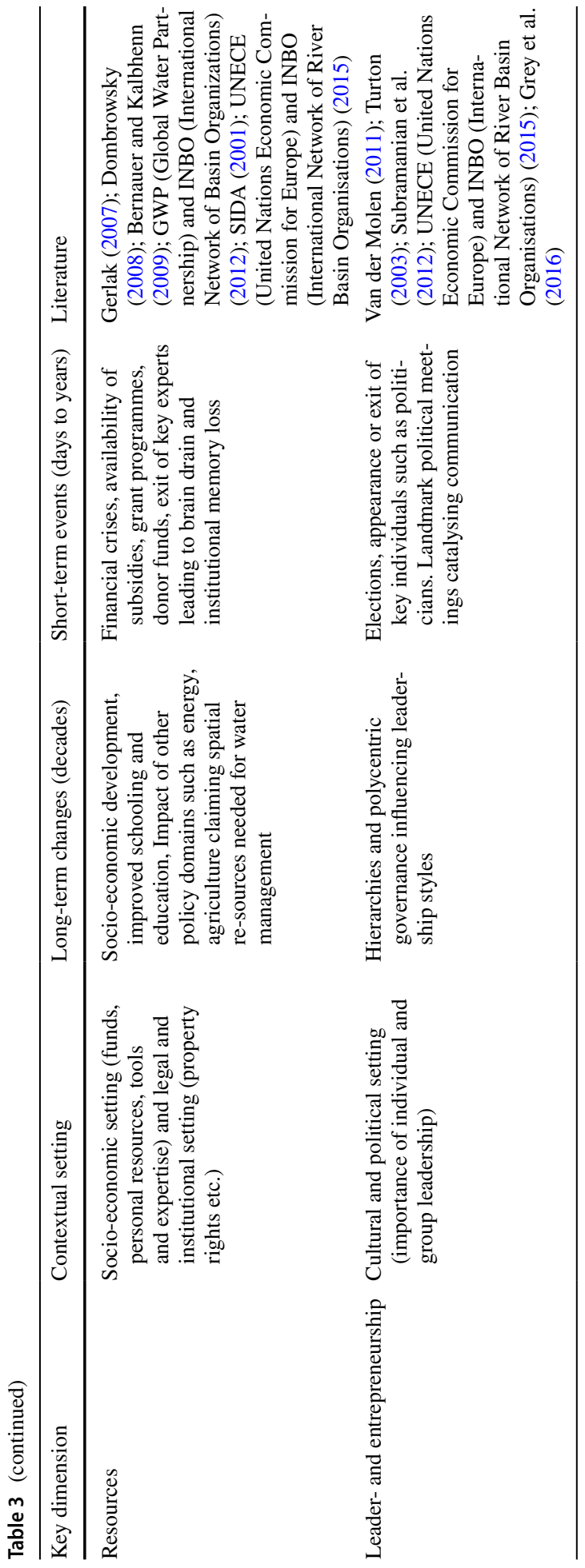




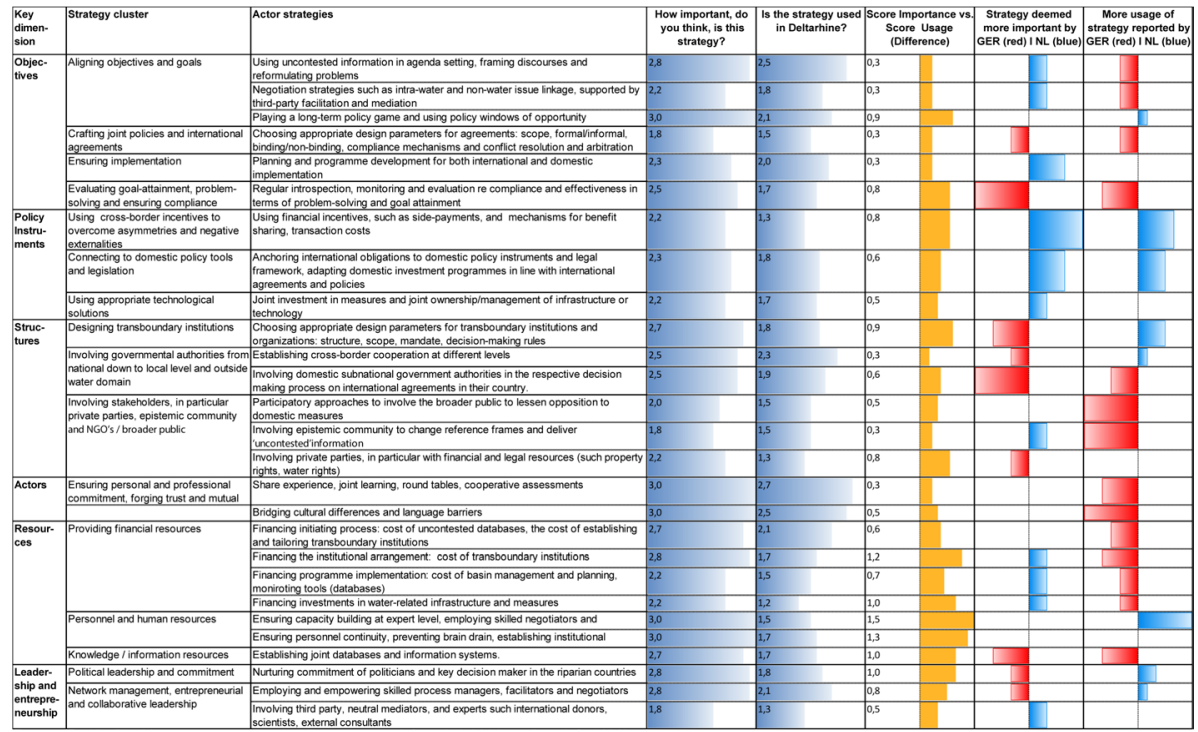

Fig. 3 Application of the assessment framework to Deltarhine

is mostly organised and shaped at the subnational level. Water-related issues in the study area are flood protection, water shortage, hydromorphological degradation due to extensive river regulation, as well as water pollution in surface waters, mostly from diffuse sources (Keetman 2006; Van Leussen et al. 2007; Van der Molen 2011; Wiering et al. 2010). In terms of regime effectiveness regarding compliance and problem-solving, it was found that bilateral water treaties from the 1960s and 1970s, dealing with limited, operational water management issues, have led to an operationalised water regime, where joint agreements on paper are turned into practice. With regard to more intractable problems such as diffuse water pollution or ecological river restoration, the regime has only very recently and at a slow pace begun to move towards joint policy making and implementation; this has been documented in separate research on regime performance and effectiveness in the study area (Renner et al. 2017, 2018).

The assessment is based on interviews with key individuals, 3 from the Netherlands and 3 from Germany, who have actively been involved in forming and shaping cross-border cooperation in the study area in the past 5-10 years. In identifying and seeking out these respondents, we build on earlier research on the role of practitioners and policy entrepreneurs in the study area (Van Herten 2011; Renner and Meijerink 2018; Renner et al. 2018). In Fig. 3 we visualize the assessment results in tabular form, the individual anonymised scoring tables for each respondent as well as for each country are provided, for the interested reader, in the ESM, Table S4. The table shows in the first column, the importance that respondents have assigned to a specific strategy, in the second column to what extent this strategy is employed in Deltarhine and in the third column, the difference between the assigned importance and actual usage. The last 2 columns document the different perceptions of the German and Dutch participants of how important they deem strategies and to what extent they are used. The numerical scores are qualitative in nature and illustrate the relative importance that is assigned by respondents to particular strategies and their usage. 
Seven main findings from the assessment are reported here. First, there is generally broad agreement that the listed range of the strategies is used to some extent, and that most are important or even crucial to cross-border cooperation in Deltarhine. The range of strategies was deemed comprehensive and additional strategies were not suggested (this was explicitly asked as well as non-occurrence). Second, there are pronounced differences between the respondents, even from one country, on how they assessed the importance of particular strategies-reflecting differences in the perceptions and mental maps of the practitioners. Third, some strategies are unanimously seen as crucial by all respondents, such as playing a long-term game and using policy windows, mutual trust building and forging professional and personal relationships or ensuring capacity building and personnel continuity. Others are deemed less important in the context of Deltarhine, e.g. choosing appropriate design parameters for legal agreements such as water treaties, or involving third parties as facilitators and mediators. Fourth, systematic differences are found between Dutch and German respondents regarding the importance of particular strategies, for example Dutch respondents give preference to use financial incentives (side payments or benefit sharing), while German respondents place more emphasis on regular introspection and evaluation. Fifth, there are differences between German and Dutch respondents when they assess whether specific strategies are indeed already employed in Deltarhine, with German respondents giving higher overall assessment scores. Sixth, respondents have indicated for some strategies that they are important or even crucial but rather not yet employed in Deltarhine, indicating the necessity to act, for example to ensure personnel capacity and continuity, exploiting policy windows or to finance transboundary institutions. Finally, respondents expressed their appreciation for the structured discussion of actor strategies. They indicated, that they were hardly using analytical or conceptual frameworks in their daily work and were interested to discuss the findings in joint Dutch-German discussions with their counterparts (beyond the scope of this study).

\subsection{Dealing with shock events and long-term changes in Deltarhine}

The Deltarhine regime has been embedded in an evolving institutional, legal, political, cultural, and socio-economic context, where domestic institutions were restructured, legal frameworks were redefined (with the introduction of the European Water Framework Directive), financial crises took socio-economic tolls and international relations between Germany and Netherlands continually improved over the past decades (Renner et al. 2018). Clustered in the six key dimensions, Table 4 lists relevant long-term changes and shortterm events that impacted on cross-border cooperation in Deltarhine since the 1990s. More information on the evolution of the Deltarhine regime and contextual factors is provided in the ESM, Table S3.

The assessment shows that the Deltarhine regime has displayed an impressive continuity over the course of the past decades, demonstrating a remarkable resilience and adaptive capacity to long-term trends and short-term events, with an expanding scope as well as a steadily increasing intensity of cross-border cooperation since the 1990s. In separate publications, it has been shown and described how actors have dealt with regime changes (Renner et al. 2017, 2018) by using a variety of adaptive strategies over time, such as: (1) framing and idea development to adapt to different German and Dutch discourses as well as changing legal requirements such as the European Water Directives, (2) exploitation and manipulation of venues to deal with changing institutional and organizational frameworks in both countries (mergers, mandate changes), (3) the orchestration and management of 


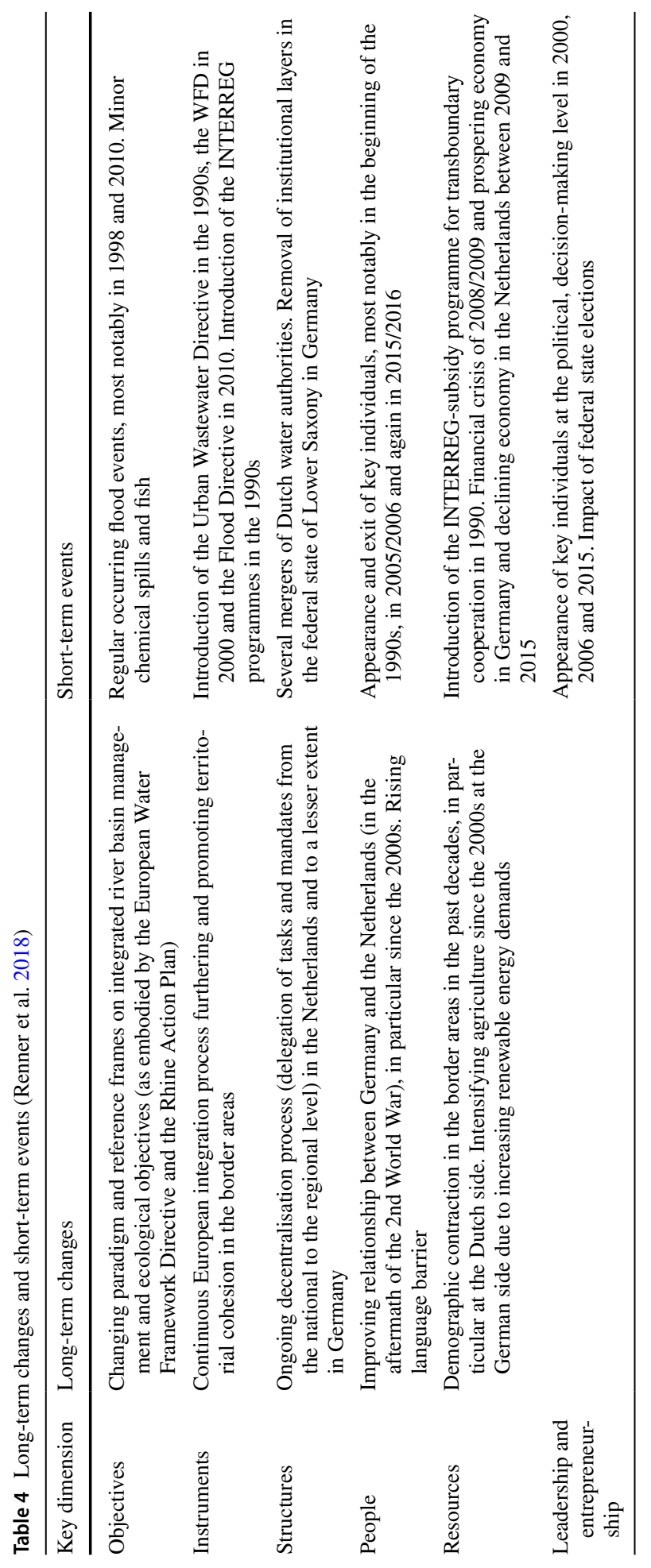


cross-border networks to deal with changing cultural attitudes and (rising) language barriers and lastly recognizing and incidentally exploiting problem windows (floods) and windows of opportunity (INTERREG) to advance and promote cross-border cooperation.

\section{Discussion and conclusions}

\subsection{Pragmatic assessment framework complementing explanatory modelling}

The developed assessment framework is intended to serve as a pragmatic assessment tool for researchers as well as practitioners to explore the available arsenal of actor strategies in international river basins. It is not intended as a comprehensive, explanatory model but rather as a simplified, conceptual tool serving the practical purpose of assessment and decision-making (Mollinga 2010, p. 5). Indeed from our findings, 2 major reasons can be discerned why it has proven problematic to establish comprehensive cause-effect relationships between explanatory factors on one hand and observations on how well a transboundary water regime might perform on the other hand.

First, there is a multitude of independent variables, i.e. explanatory factors (see extended Table S2, ESM), which greatly outnumber the dependent variables, such as measurements of regime effectiveness. From systems theory it is known that in complex systems, different combinations of model variables can yield the same model results, resulting in equifinality (Von Bertalanffy 1964; Beven 2005). This is mirrored in the literature on transboundary water management where authors have pointed out the large number of candidate explanations and subsequently the difficulties of transferring lessons of success or failure from one river basin to another (Bernauer 2002; Mostert 2005). Second, the availability of empirical data and information will in practice determine where to draw analytical and exploratory boundaries. Explanatory efforts will meet analytical limits, for example when 'drilling down' analytically to the level of key individuals and their motivations, cognitions and specific strategies they employ (Bressers 2007). As Öjendahl, Earle et al. 2013) have remarked, it is difficult for outside researchers to study processes of transboundary water management in detail due to their opaqueness, especially in more intractable cases. For a researcher to get to know the inner workings of cross-border cooperation, for example to explore in detail the perceptions and negotiation strategies of actors or even key individuals, does not only demand considerable resources but also requires to be intensively inquisitive as to the point of becoming involuntarily a participant instead of an observer of cross-border cooperation.

Various authors have thus cautioned against simple transfer of experiences and policy recommendations from one international river basin to another (Bernauer 2002 and 2010; Lindemann 2008; Marty 2001; Mostert 2003; Verwijmeren and Wiering 2007; Schmeier 2010), pointing the unique set of circumstances of each river basin, and some authors even doubting whether it is possible to develop a coherent analytical framework and to draw general inferences. At the same time, there is the increased urgency for the practitioners of international river basin management to go beyond a mere trial-and-error approach and to learn from the experience of others. The assessment framework used in this study is therefore seen as complementary to causal, explanatory modelling since it 'translates' a broad range of explanatory factors into action-oriented process and management strategies and serves as a 'checklist' and toolbox for practitioners to assess which strategies they could 
employ, as well as to provide assistance and advice to policy and key decision-makers (Mollinga 2010).

\subsection{Appraisal of the current assessment framework}

In developing an assessment framework, we build on scientific and practitioners literature, anchoring the framework in social science theory on complex governance regimes as well as applying and testing the framework in the Dutch-German water regime of Deltarhine. Looking at the findings, several observations regarding the applicability and limitations of the current framework are provided:

Drawing an overall picture The six key dimensions allow to group and cluster a broad range of actor strategies by covering what has been called the micro-, meso- and macrolevels of analysis in the socio-technical systems literature (Rotmans et al. 2001, Dewulf et al. 2009). Transboundary water management is at the macro-level shaped and formed by contextual characteristics, including long-term changes as well as shock events (as discussed in Sects. 4.2 and 5.2), with which actors must deal with using adaptive strategies and which sometimes can be purposefully exploited (Kingdon 1997). At the meso-level, we find multiple strategies to align goals and negotiate treaties, to formulate the rules of the game and build transboundary institutions as well as securing sufficient resources. At the micro-level, we finally see the behaviour of key individuals, decision-makers and practitioners, and the entrepreneurial strategies they employ as central elements. Complementing the assessment framework with the perspective and key dimension of leadership and entrepreneurship (Huitema and Meijerink 2009), as also earlier applied in Deltarhine (Renner and Meijerink 2018) has proven fruitful and necessary to draw an overall picture of cross-border cooperation.

Juggler's metaphor Looking at the broad range of available strategies, there is an important question, also raised by Bressers and Kuks (2013) and Gupta et al. (2010). Do all strategies have equal weight? Are all strategies equally important in a particular river basin? An argument might be made, based on the broad range of factors and strategies supplied by the literature, that employing a broad range of actor strategies increases the chances and likelihood of progressing towards policy implementation and actual problem-solving in international river basins. The juggler's metaphor, used by some authors (Van der Molen 2011), seems apt to stress the importance of simultaneously pursuing multiple strategies as an essential characteristic of steering and managing cross-border cooperation. Application in the Deltarhine case indicates a broad practitioners' appreciation of the comprehensive toolbox of strategies; however, clearly some strategies are assessed to be more important and crucial than others.

Perceptions of practitioners and key individuals The assessment framework allows to explore the perceptions of practitioners and key individuals in cross border cooperation which strategies they deem crucial and actively use in cross-border cooperation. It is interesting and instructive to investigate what weighting and relative importance is assigned by actors and individuals to specific actor strategies. Do upstream and downstream countries for example have similar perceptions on the importance of using uncontested information or mutual confidence building? The results from Deltarhine show that there are different perceptions of specific strategies in cross-border cooperation between German and Dutch participants. These have been made explicit and interest has been expressed to discuss the findings in subsequent international meetings. Key individuals and practitioners are mostly unaccustomed to consciously reflect on strategies; they appear to apply mostly a 
trial-and-error approach and 'learning on the job'. They regarded the assessment framework as valuable to structure their thought process and discussion with their counterparts.

Methodological appraisal Clearly, the assessment framework is work in progress and we learned from its application and testing in Deltarhine. On a general note, it was found that the strategies can be analysed and assessed in further detail if needed, see for example publications on specific design parameters of international water treaties (Schmeier et al. 2015) or detailed negotiation strategies (Mostert 2005). However, such in-depth analysis of a particular river basin or cross-case comparisons is strongly dependent on the (often limited) availability of empirical data (Bernauer 2002). Furthermore, the individual scores for specific strategies could be aggregated into overall scores for the key dimensions, enabling cross-case comparisons. Using aggregated scores is tempting-but are the key dimensions and assessment criteria indeed independent of each other? Bressers and Kuks (2013, p. 138) have argued that "key dimensions of governance regimes each form part of the context of the others", and that the apparent complexity of governance regimes does not only stem from the number of explanatory factors but also their interconnectedness and relationships. Gupta et al. (2010) in developing their assessment tool have also pointed out the interdependence, sometimes even tensions, between assessment criteria.

With these caveats in mind, it might be interesting to further explore actor strategies in cross-case comparisons of international river basins. However, in order to do so, we recognize the limitations of the methodology and qualitative scoring used in this single case study to map and document the perceptions of actors. For robust methodological framing and to compare actor strategies in different river basins, two suggestions are offered. First, make data collection, scoring and aggregation and subtraction procedures part of a research protocol and the overall assessment framework itself, in particular when comparing between different international river basins and different venues of cross-border cooperation. Second, it is suggested to extend the 3-point scale in this case study and instead using more elaborate 5 or 7 point rating scales to generate interval data for further quantitative analysis, aggregation and cross-case comparison. Respondents themselves indicated in some cases that five-scale scoring would provide more nuance and flexibility by assigning scores of 1,5 and 2, 5 .

Application of the framework in other international river basins The framework was applied and tested in a Dutch-German case study, essentially taking place in what Durth (1996) has called an integrated context, with the 2 neighbouring countries, Germany and the Netherlands, having similar cultural roots, common historical background, joint supranational European legal framework and a cooperative transboundary water regime (Renner et al. 2018). How would assessment of actor strategies work out in international river basins with non-integrated and non-democratic contexts, strong asymmetric power constellations and characterised by distrust between riparians? How could the assessment framework be used in river basins with a hydro-hegemon, as described by Zeitoun and Warner (2006)? Öjendal et al. (2013) have for example pointed out that negotiations over securitised water resources are by definition not in the public domain and only limited and inferred observations will be possible. Based on our study, 2 reflections are offered: First, we strongly support the argument of Earle et al. (2013) to involve practitioners in systematic review of experiences 'from-theinside' to complement 'from-the-outside' research by social scientists as it is crucial to document, probe and assess the strategies, that key individuals such as negotiators, conveners, delegation leaders, or mediators employ in opaque, non-integrated settings. Second, we suggest that the assessment framework can serve also in non-integrated and hydro-hegemony contexts as an instrument to open and facilitate dialogue between 
riparian countries. Though distrust and unwillingness to engage in dialogue may hamper application, the framework nevertheless allows to map and analyse in a reasonably simple and structured manner the importance of particular strategies, for example what importance the different riparians assign to using uncontested information, crafting joint agreements, regularly monitor progress or obtaining commitment of key politicians; and even more crucially, to separately document their perceptions on how these strategies are already actually used. This is key to juxtaposing and jointly discussing those perceptions as well as contrasting them with the actual track record of cooperation. Alternatively and as mentioned earlier, the assessment framework can be put to use, for example by downstream countries as a 'checklist', to assess and coordinate their range of strategies on the national, regional and local level in order to engage and influence their riparian upstream counterparts.

\subsection{Policy recommendations and opening dialogue in Deltarhine}

This study focused on developing an assessment framework for actor strategies, and we are reluctant to provide general policy advice to avoid the fallacy of drawing hasty conclusions on a too narrow empirical basis and a limited number of respondents from the Deltarhine case. Therefore, only a few specific policy recommendations are provided for Deltarhine, in particular with a view towards the limited regime effectiveness in terms of problem-solving in the study area in the past 2 decades (Renner et al. 2018). The respondents are practitioners in the Dutch-German cross-border cooperation and have unanimously expressed their interest to open the dialogue with their counterparts to jointly discuss the findings and policy recommendations of this study, pointing to an open and trustful atmosphere between both riparian countries in the Deltarhine area:

- Address and implement strategies that are considered important or crucial but may not yet sufficiently used in Deltarhine, such as: making use of particular policy windows of opportunity and shock events (Table 4), designing and adequately financing transboundary institutions, ensuring personnel capacity and continuity, and nurturing commitment of politicians and key decision-makers.

- Discuss the marked differences in perceptions between individuals on the importance of particular strategies, such as the need and necessity for financing instruments or getting the institutional design of transboundary organisations right.

- Reflect on the fact, that practitioners in Deltarhine attach less importance to (design parameters of) water treaties and formal transboundary agreements, than might be expected from the abundance of the broader scientific literature and practitioner's guidelines.

- Explore the fact, that consistently higher assessment scores are assigned by the German upstream partners than the Dutch downstream partners to the actual usage of particular strategies (last column in Fig. 3), i.e. there are systematically different perceptions of strategies already being put to use in Deltarhine.

- Play the long-term game and continue the decade-long tradition of cross-border cooperation in Deltarhine marked by mutual confidence building and maintaining long-term personal and professional relationships over time. 


\subsection{Connecting science and practice}

In the literature and our empirical research in Deltarhine, we found ample evidence that scientific technical knowledge and information is applied in transboundary water management, for example when it comes to building hydrological models or devising technological infrastructure solutions. Surprisingly, there is less evidence that practitioners use conceptual frameworks or tools derived from social sciences to assess and organise cross-border cooperation in international waters. It is therefore a fundamental challenge to put the rich body of social science literature to use (Armitage et al. 2015). Practice and action-oriented studies are in our view useful complements to practical hands-on experience, by not only providing policy recommendations for specific river basins, but also by stimulating practitioners to engage in action research and enabling them to use mental maps and conceptual frameworks, such as the assessment framework developed and used in this study, to deal with the layered complexity of transboundary water governance.

Acknowledgements The authors kindly thank all respondents from Germany and The Netherlands for their kind participation in this study. The authors also thankfully acknowledge the constructive reviews of two anonymous reviewers who have helped to improve the paper. Underlying data for this paper are properly cited and referred to in the reference list and the appendices. Supporting data are included as seven tables in the corresponding Electronic Supplemental Material (ESM)

Open Access This article is licensed under a Creative Commons Attribution 4.0 International License, which permits use, sharing, adaptation, distribution and reproduction in any medium or format, as long as you give appropriate credit to the original author(s) and the source, provide a link to the Creative Commons licence, and indicate if changes were made. The images or other third party material in this article are included in the article's Creative Commons licence, unless indicated otherwise in a credit line to the material. If material is not included in the article's Creative Commons licence and your intended use is not permitted by statutory regulation or exceeds the permitted use, you will need to obtain permission directly from the copyright holder. To view a copy of this licence, visit http://creativecommons.org/licenses/by/4.0/.

\section{References}

Armitage, D., De Loë, R. C., Morris, M., Edwards, T. W., Gerlak, A. K., Hall, R. I., et al. (2015). Sciencepolicy processes for transboundary water governance. Ambio, 44(5), 353-366. https://doi.org/10.1007/ s13280-015-0644-x.

Arts, B., \& Van Tatenhove, J. (2000). Policy arrangements. political modernisation and the environment: The renewal of environmental policy arrangements. Dordrecht, Netherlands: Kluwer Academic Publishers.

Backer, E. (2006). Paper tiger meets white elephant? an analysis of the effectiveness of the mekong river regime. FNI Report 15/(2006). Oslo, Norway: The Fridtjof Nansens Institute.

Barnaby, W. (2009). Do nations go to war over water? Nature, 458(7236), 282-283. https://doi. org/10.1038/458282a.

Bernauer, T. (1996). Protecting the rhine river against chloride pollution. In R. O. Keohane \& M. A. Levy (Eds.), Institutions for environmental aid: Pitfalls and promise. Cambridge: MIT Press.

Bernauer, T. (1997). Managing international rivers. In O. R. Young (Ed.), Global governance: Drawing insights from the environmental experience (pp. 155-195). Cambridge: MIT Press.

Bernauer, T. (2002). Explaining success and failure in international river management. Aquatic Sciences, $64,1-19$.

Bernauer, T., \& Böhme, H. (2014). Basins at risk-Predicting international river basin conflict and cooperation. Global Environmental Politics. https://doi.org/10.1162/GLEP_a_00260. 
Bernauer, T., \& Kalbhenn, A. (2009). The politics of international freshwater resources. In N. R. F. AlRodhan (Ed.), Potential global strategic catastrophes: Balancing transnational responsibilities and burden-sharing with sovereignty and human dignity. Berlin: LIT.

Bernauer, T., \& Siegfried, T. (2008). Compliance and performance in international water agreements: The case of the Naryn/Syr Darya Basin. Global Governance, 14(4), 479-501.

Beven, K. (2005). A manifesto for the equifinality thesis. Journal of Hydrology, 20, 1-19.

Bressers, J.T.A. (2007). Contextual interaction theory and the issue of boundary definition: Governance and motivation, cognitions and resources of actors. CSTM series Studies and Reports; No. 323. Enschede, Netherlands: Center for Clean Technology and Environmental Policy.

Bressers, J. T. A., \& Kuks, S. (2013). Water governance regimes: Dimensions and dynamics. International Journal of Water Governance, 1(2013), 133-156. https://doi.org/10.7564/12-IJWG1.

Brouwer, S. \& Huitema, D. (2015). Reasoning about strategies for policy change: The assessment of policy entrepreneurs. Paper for COST Action: IS1309 WG1 meeting - Policy entrepreneurship and policy innovation, 18/05/2015, Institute For Environmental Studies, VU University, Amsterdam, Netherlands.

Daoudy, M. \& Kistin, E. (2008). Beyond water conflict: Evaluating the effects of international water cooperation. Paper prepared for the 49th annual conference of the international studies association. San Francisco, US, 26-29 March 2008.

De Stefano, L., Duncan, J., Dinar, S., Stahl, K., Strzepek, K., \& Wolf, A. T. (2010). Climate change and the institutional resilience of international river basins. Journal of Peace Research, 49(1), 193-209. https ://doi.org/10.1177/0022343311427416.

Delli Priscoli, J., \& Wolf, A. T. (2009). Managing and transforming water conflicts. New York: Cambridge University Press.

Dewulf, A., Termeer, C., Werkman, R., Breeman, G., \& Poppe, E. (2009). Transition management for sustainability: Towards a multiple theory approach. In E. Poppe, C. Termeer, \& M. Slingerland (Eds.), Transitions towards sustainable agriculture and food chains in peri-urban areas. Academic Publishers: Wageningen.

Dieperink, C. (1997). Tussen zout en zalm: Lessen uit de ontwikkeling van het regime inzake de Rijnvervuiling. Amsterdam: Thesis Publishers.

Dieperink, C. (2002). The clean up of the Rhine as a successful international effort. In I. Al Baz, V. Hartje, W. Scheumann (Eds.), Co-operation on transboundary rivers. Baden Baden: Nomo Verlagsgesellschaft.

Dinar, A. (2007). Bridges over water: Understanding transboundary water conflict, negotiation and cooperation. Singapore: World Scientific Publishing.

Dinar, S. (2008). International water treaties - Negotiation and cooperation along transboundary rivers. London: Routledge.

Dombrowsky, I. (2007). Conflict, cooperation and institutions in international water management: An economic analysis. Cheltenham: Elgar.

Dombrowsky, I. (2008). Institutional design and regime effectiveness in transboundary river management the Elbe water quality regime. Hydrology and Earth System Sciences, 12, 223-238.

Drieschova, A., Giordano, M., \& Fischhendler, I. (2008). Governance mechanisms to address flow variability in water treaties. Global Environmental Change, 18(2), 285-295.

Durth, R. (1996). Transboundary environmental problems and upstream-downstream constellations in international rivers. Baden-Baden: Nomos Verlag.

Earle, A., Jägerskog, A., \& Öjendal, J. (2013). Transboundary water management-Principles and practice. London: Earthscan.

Finger, M., Ludivine, T., \& Allouche, J. (Eds.). (2006). The multi-governance of water. New York: State University of New York Press.

Gerlak, A. K. (2007). Lesson learning and transboundary waters: A look at the global environment facility's international waters program. Water Policy, 9(1), 55-72.

Grey, D.; Sadoff, C. \& Connors, G. (2016). Effective cooperation on transboundary waters: A practical perspective. World Bank Policy Brief. Washington D.C, US: World Bank.

Gupta, J., Termeer, C., Klostermann, J., Meijerink, S., van den Brink, M., Jong, P., et al. (2010). The adaptive capacity wheel: A method to assess the inherent characteristics of institutions to enable the adaptive capacity of society. Environmental Science and Policy, 13(6), 459-471. https://doi.org/10.1016/j. envsci.(2010).05.006.

GWP and INBO. (2012). The handbook for integrated water resources management in transboundary basins of rivers, lakes and aquifers. Stockholm: GWP.

Hinkel, J., \& Menniken, T. (2007). Climate change and institutional adaptation in transboundary river basins. technical paper. Vientiane, Lao PDR: Mekong River Commission.

Hofstede, G. (1991). Cultures and organizations: Software of the mind. London: McGraw-Hill. 
Huitema, D., \& Meijerink, S. (Eds.). (2009). Water policy entrepreneurs: A research companion to water transitions around the globe. Cheltenham: Edward Elgar Publishing.

Huntjens, P. (2011). Water management and water governance in a changing climate. Utrecht: Eburon.

IRBM Deltarhine (2009). International river basin management plan Deltarhine 2009-2015. Technical Report. Bonn, Germany: German Federal Ministry of Water Affairs.

Jones, B. D., \& Baumgartner, F. R. (2012). From there to here: Punctuated equilibrium to the general punctuation thesis to a theory of government information processing. The Policy Studies Journal, 40(1), $1-20$.

Keetman, W. (2006). Grensoverschrijdende samenwerking in de regio. Unie van Waterschappen. The Hague: Association of Dutch Water Authorities.

Kingdon, J. W. (1997). Agendas, alternatives and public policies. London: Longman.

Le Marquand, D. (1977). International rivers: The politics of cooperation. Vancouver: University of British Columbia, Westwater Research Centre.

Levy, M. A., Young, O. R., \& Zürn, M. (1995). The study of international regimes. European Journal of International relations, 1995(1-3), 267-330.

Lindemann, S. (2008). Understanding water regime formation-A research framework with lessons from europe. Global Environmental Politics, 8(4), 117-140.

Lugo, C. (2010). Analyzing the effectiveness of transboundary water regimes: The case of lake victoria basin, East Africa. PhD Thesis. University of East Anglia, Norwich, United Kingdom.

Marty, F. (1997). International river management-The political determinants of success and failure, Studien zur Politikwissenschaft 305. Zurich: University of Zurich.

Marty, F. (2001). Managing international rivers: Problems, politics and institutions. Bern: Peter Lang.

Meijerink, S. (1998). Conflict and cooperation on the scheldt river basin: A case study of decision making on international scheldt issues between 1967 and (1997). Boston: Kluwer Academic Publishers.

Meijerink, S., \& Huitema, D. (2010). Policy entrepreneurs and change strategies: Lessons from sixteen case studies of water transitions around the globe. Ecology and Society, 15(2), 21.

Mingst, K. A. (1981). The functionist and regime perspectives: The case of Rhine river cooperation. Journal of Common Market Studies, 20, 161-173.

Mintrom, M., \& Norman, P. (2009). Policy entrepreneurship and policy change. Policy Studies Journal, 37, 649-667. https://doi.org/10.1111/j.1541-0072.2009.00329.x.

Mollinga, P. P. (2010). Boundary work and the complexity of natural resources management. Crop Science, 50, S1-S9. https://doi.org/10.2135/cropsci2009.10.0570.

Mostert, E. (2003). Conflict and cooperation in the management of international freshwater resources: A global review. International Journal of River Basin Management, 1(3), 1-12.

Mostert, E. (2005). How can international donors promote transboundary water management? discussion paper. Bonn: Deutsches Institut für Entwicklungspolitik.

Mostert, E. (2008). The many sources of the management of the Rhine. IWHA(2007) Book of Abstracts. Tampere, Finland: International Water History Association.

Öjendal, J., Earle, A., \& Jägerskog, A. (2013). Towards a conceptual framework for transboundary water management. In A. Earle, A. Jägerskog, \& J. Öjendal (Eds.), Transboundary water managementprinciples and practice. London: Earthscan.

Pahl-Wostl, C. (2009). A conceptual framework for analysing adaptive capacity and multi-level learning processes in resource governance regimes. Global Environmental Change, 19(2009), 354-365. https://doi.org/10.1016/j.gloenvcha.2009.06.001.

Pahl-Wostl, C., Holtz, G., Kastens, B., \& Knieper, C. (2010). Analyzing complex water governance regimes: The management and transition framework. Environmental Science and Policy, 13(7), 571-581. https://doi.org/10.1016/j.envsci.(2010).08.006.

Raadgever, G. T., Mostert, E., Kranz, N., Interwies, E., \& Timmerman, J. G. (2008). Assessing management regimes in transboundary river basins: do they support adaptive management? Ecology and Society, 13(1), 14.

Renner, T., \& Meijerink, S. (2018). Policy entrepreneurs in international river basins-getting climate adaptation on the cross-border water policy agenda. Regional Environmental Change, 18(5), 12871298. https://doi.org/10.1007/s10113-017-1178-5.

Renner, T., Meijerink, S., \& Van der Zaag, P. (2017). The evolution of regional cross-border water regimes, the case of Deltarhine. Journal of Environmental Planning and Management, 61(10), 1701-1721. https://doi.org/10.1080/09640568.2017.1371005.

Renner, T., Meijerink, S., \& Van der Zaag, P. (2018). Progress beyond policy making? Assessing the performance of Dutch-German cross-border cooperation in Deltarhine. Water International, 43(7), 996-1015. https://doi.org/10.1080/02508060.2018.1526562. 
Sabatier, P. A., \& Jenkins-Smith, J. C. (Eds.). (1993). Policy change and learning: An advocacy coalition approach. Boulder: Westview Press.

Sadoff, C. W., \& Grey, D. (2002). Beyond the river: The benefits of cooperation on international rivers. Water Policy, 4(5), 389-403.

Santbergen, L. (2013). Ambiguous ambitions in the meuse theatre. Utrecht: Eburon.

Savenije, H. G., \& Van der Zaag, P. (2000). Conceptual framework for the management of shared river basins; With special reference to the SADC and EU. Water Policy, 2, 9-45.

Schmeier, S. (2010). Governing international watercourses-perspectives from different disciplines. A comprehensive literature review. Hertie School of Governance, Working Papers 53-2010. Bonn, Germany, HSG.

Schmeier, S., Gerlak, A. K., \& Blumstein, S. (2015). Clearing the muddy waters of shared watercourses governance: Conceptualizing international river basin organizations. International Environmental Agreements, 16(4), 597-619. https://doi.org/10.1007/s10784-015-9287-4.

SIDA. (2001). Transboundary water management as an international public good. Technical report. Stockholm, Sweden: SIDA.

Skjaerseth, J. B. (2000). North sea cooperation: Linking international and domestic pollution control. New York: Manchester University Press.

Soeters, J. (1993). Managing euregional networks. Organization Studies, 14(5), 639-656.

Subramanian, A., Brown, B., \& Wolf, A. T. (2012). Reaching across the waters: Facing the risks of cooperation in international waters. Washington, DC, US: World Bank.

TFDD (Transboundary Freshwater Dispute Database) (2017). International water event database: 19502015. Oregon State University, Department of Geosciences.

Timmerman, J. G., Koeppel, S., Bernardini, F., \& Buntsma, J. J. (2011). Adaptation to climate change: Challenges for transboundary water management. In W. L. Filho (Ed.), The economic, social and political elements of climate change. Berlin: Springer.

TPRW. (2014). Minutes of meetings, notes and reports of the steering group, strategic working group and expert groups. Gronau: TPRW (Transboundary Platform for Regional Water Management)

Tschanz, R. (2001). Gewässerschutz am Rhein: Zur Lösung von grenzüberschreitenden Umweltschutzproblemen. M.A. thesis. Zurich, Switzerland, Swiss Federal Institute of Technology (ETH), Center for International Studies.

Turton, A. (2003). The political aspects of institutional developments in the water sector: South Africa and its international river basins. PhD thesis. University of Pretoria, South Africa.

Underdal, A. (1992). The concept of regime 'Effectiveness'. Cooperation and Conflict, 27, 227-242.

UNDP. (2006). Beyond scarcity: power, poverty and the global water crisis. Human Development Report. New York, US: UNDP.

UNECE and INBO. (2015). Water and climate change adaptation in transboundary basins: Lessons learned and good practices. Geneva: UNECE.

UNEP. (2016). Transboundary river basins: Status and trends, summary for policy makers. Nairobi: UNEP.

UNESCO. (2004). From potential conflict to co-operation potential: Promoting water as a catalyst for peace through capacity building, research and technical assistance. Contribution of UNESCO's International Hydrological Programme to the World Water Assessment Programme. Paris, France: UNESCO.

Van der Molen, J. (2011). Crossing Borders: Een kader voor het tot ontwikkeling brengen van grensoverschrijdende samenwerking. PhD thesis. University of Twente, Almelo, Netherlands.

Van der Zaag, P., \& Vaz, C. A. (2003). Sharing the incomati waters: Cooperation and competition in the balance. Water Policy, 5(2003), 349-368.

Van Herten, M. (2011). Bridging the Dutch-German border, towards effective water management in transboundary river basins. BSc thesis. Utrecht University, Netherlands.

Van Leussen, W., Van Slobbe, E. \& Meiners, G. (2007). Transboundary governance and the problem of scale for the implementation of the European WFD at the Dutch-German Border. Working paper, Research Gate.

Verwijmeren, J., \& Wiering, M. (2007). Many rivers to cross. Utrecht: Eburon.

Von Bertalanffy, L. (1964). The history and status of general systems theory. The Academy of Management Journal, 15(4), 407-426.

Warner, J., \& Zawahri, N. (2012). Hegemony and asymmetry: Multiple-chessboard games on transboundary rivers. International Environmental Agreements, 12(2), 215. https://doi.org/10.1007/s10784-012-9177-y.

Wiering, M., \& Verwijmeren, J. (2013). Limits and borders: Stages of transboundary water management. Journal of Borderland Studies, 27(3), 257-272. https://doi.org/10.1080/08865655.2012.750949.

Wiering, M., Verwijmeren, J., Lulofs, K., \& Feld, C. (2010). Experiences in regional cross border co-operation in river management comparing three cases at the Dutch-German border. Water Resources Management, 24(11), 2647-2672. https://doi.org/10.1007/s11269-009-9572-5. 
Wolf, A. T., Stahl, K., \& Macomber, M. F. (2003a). Conflict and cooperation within international river basins: The importance of institutional capacity. Carbondale: UCOWR.

Wolf, A. T., Yoffe, S. B., \& Giordano, M. (2003b). International waters: Identifying basins at risk. Water Policy, 5(2003), 29-60.

Young, O. R. (1982). Regime Dynamics: The rise and fall of international regimes. International Organization, 36(2), 277-297.

Young, O. R. (1991). Political leadership and regime formation: On the development of institutions in international society. International Organization, 45, 281-308.

Young, O. R. (1999). The effectiveness of international environmental regimes. Cambridge: MIT Press.

Young, O. R. (2001). Inferences and indices: Evaluating the effectiveness of international environmental regimes. Global Environmental Politics, 1, 99-121. https://doi.org/10.1162/152638001570651.

Young, O. R., \& Osherenko, G. (1993). The formation of international regimes: Hypotheses and cases. In O. R. Young \& G. Osherenko (Eds.), Polar politics: Creating international environmental regimes (pp. 1-21). Ithaca, New York: Cornell University Press.

Zeitoun, M., \& Mirumachi, N. (2008). Transboundary water interaction I: Reconsidering conflict and cooperation. International Environmental Agreements, 8(2008), 297-315. https://doi.org/10.1007/s1078 4-008-9083-5.

Zeitoun, M., \& Warner, J. (2006). Hydro-Hegemony: A framework for analysis of transboundary water conflicts. Water Policy, 8(2006), 435-460.

Publisher's Note Springer Nature remains neutral with regard to jurisdictional claims in published maps and institutional affiliations.

\section{Affiliations}

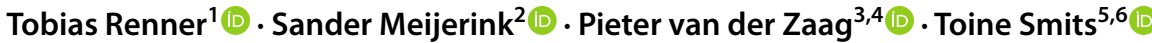

Sander Meijerink

s.meijerink@fm.ru.nl

Pieter van der Zaag

p.vanderzaag@un-ihe.org

Toine Smits

A.Smits@ science.ru.nl

1 Institute for Science in Society, Radboud University, P.O. Box 9010, 6500 GL Nijmegen, The Netherlands

2 Institute for Management Research, Radboud University, P.O. Box 9108, 6500 HK Nijmegen, The Netherlands

3 IHE Delft Institute for Water Education, Delft, The Netherlands

4 Water Resources Section, Delft University of Technology, Delft, The Netherlands

5 Institute for Science in Society, Radboud University, Nijmegen, The Netherlands

6 Delta Areas and Resources, Van Hall Larenstein University of Applied Sciences, Velp, The Netherlands 